\title{
PENGARUH INFLASI DAN KURS TERHADAP HARGA SAHAM DI INDUSTRI DASAR DAN KIMIA
}

\author{
Dian Efriyenty \\ Program Studi Akuntansi Fakultas Ilmu Sosial dan Humanioura Universitas Putera Batam Jl. R. Soeprapto \\ Muka Kuning, Kibing, Batam, Indonesia, 29434 \\ E-mail: dianefriyenty@gmail.com
}

\begin{abstract}
The higher the stock price, the financial condition of the company will look more stable and stronger, while when the stock price of a company decreases, the financial condition of the company will look unstable and weaker. The population taken from industrial and chemical manufacturing companies in the 2015-2019 period was 74 companies. The sample collection technique uses the purposive sampling method. The sample used in this study was 18 companies. The results of the study using the t test showed that partially inflation positively did not have a significant effect on stock prices while and exchange rates positively did have a significant effect on stock price.
\end{abstract}

Keywords: inflation; exchange rates; stock price

\section{PENDAHULUAN}

Perusahaan di berbagai negara ini lama saling bersaing, dari persaingan tersebut perusahaan akan mendapatkan keuntungan dan kerugian. Perusahaan dalam persaingan tersebut akan mengurangi dana untuk tetap di depan persaingan perusahaan dengan memasukkan dana tersebut ke dalam kegiatan operasionalnya. Tetapi dana tersebut terbatas dan perusahaan mengurangkan dana tersebut untuk kegiatan lainnya. Dengan ini kebutuhan dana yang diperlukan oleh perusahaan tidaklah rendah. Salah satu solusinya, dengan menggunakan cara go public untuk menjual saham. Cara ini merupakan cara yang lancar dan murah digunakan dibandingkan melalui cara lainnya yakni, dengan melakukan pinjaman atau berutang pada pihak lain. Seseorang yang membeli saham atau dengan kata lain menginvestasi pada perusahaan tersebut dengan cara ini akan mendapatkan keuntungan yaitu mendapatkan pengembalian investasi atas perusahaan yang diinvestasi yang bisa disebut sebagai dividen. Indikator atau juga sinyal prospek sebuah perusahaan dapat dilihat dari dividen. Pada umumnya, untuk mendapatkan capital gain dan dividen merupakan tujuan dari investor. Dividen sendiri adalah laba yang telah dibagikan terhadap pemegang saham, dan capital gain itu adalah selisih antara lebih harga saham pada saat penjualan dan pembelian saham (Efriyenti, 2017).

PT. Semen Baturaja (Persero) Tbk merupakan perusahaan yang pada tahun 2015 menutup harga sahamnya sebesar Rp. 291.00 dan meningkat sebanyak Rp. 2,499.00 menjadi Rp. 2,790.00 pada tahun 2016 dan pada tahun 2017 harga saham penutupnya meningkat sebanyak Rp. 1,010.00 sehingga harga sahamnya menjadi Rp. 3,800.00 dan menurun sebanyak Rp. 2,050.00 dan menjadi sebanyak Rp. 1,750.00 pada tahun 2018 dan menurun sebanyak Rp. 1,310.00 menjadi sebanyak Rp. 440.00 pada akhir Desember 2019, ini menunjukkan bahwa menginvestasi pada perusahaan Semen Baturaja (Persero) pada awalnya merugikan dengan 2 tahun pertamanya menurun tetapi 2 tahun berikutnya harga sahamnya meningkat dengan pesat dengan tahun terakhirnya menurun ini mengatakan kalau perusahaan Semen Baturaja dapat berdampak investasi tetapi penginvestasian tersebut yang lakukan dengan risiko terhadap harga saham. 
Tabel 1. Data Kurs United States Dollar atau USD

\begin{tabular}{cccc}
\hline Tgl/Bulan/Tahun & Kurs Jual & Kurs Beli & Kurs Tengah \\
\hline 31 Desember 2015 & 13,864 & 13,726 & 13,795 \\
31 Desember 2016 & 13,503 & 13,369 & 13,436 \\
30 Desember 2017 & 13,616 & 13,480 & 13,548 \\
31 Desember 2018 & 14,553 & 14,409 & 14,481 \\
31 Desember 2019 & 13,970 & 13,831 & 13,900 \\
\hline
\end{tabular}

Sumber: http://www.bi.go.id

Selain inflasi dan kurs atau dikenal sebagai nilai tukar mata uang asing yang menunjukkan pertukaran antara mata uang terhadap mata uang asing. Melemahnya atau menguatnya kurs dapat menjadi penyebab meningkatnya atau menurunnya harga saham. Ini dikarenakan mata uang yang nilainya melemah akan berdampak pada perusahaan yang memiliki beban mata uang asing ataupun perusahaan yang sering melakukan kegiatan import. Perbedaan nilai mata uang dengan mata uang asing yang semakin melemah akan mengakibatkan perbedaan pada pembelian barang import dan kenaikan pada beban mata uang asing dan ini mengakibatkan beban perusahaan meningkat yang mengakibatkan harga saham sebuah perusahaan menurun sehingga para investor tidak yakin untuk menginvestasi pada perusahaan tersebut. Peran dari nilai tukar mata uang asing (foreign exchange) untuk negara-negara berkembang seperti Indonesia itu penting sekali, terutama untuk mata uang keras seperti Dolar AS (USD) dan Yen Jepang (JPY) (Ilham dan Nyoman, 2019). Pentingnya peran pemerintah dalam mengambil mekanisme kebijakan moneter sangat diperlukan untuk mengendalikan ekonomi ke kondisi yang lebih baik. Menjaga stabilitas ekonomi adalah tugas utama pemerintah untuk menjaga inflasi dan stabilitas nilai tukar melalui mekanisme suku bunga (Ilham dan Nyoman, 2019).

Tujuan dari riset ini untuk mengetahui apakah faktor inflasi dan kurs dapat berpengaruh secara signifikan kepada harga saham baik berpengaruh secara sendiri maupun bersama-sama. Inflasi telah terbukti berpengaruh secara signifikan dan positif kepada indeks harga saham properti inflasi berdampak secara sendiri terhadap stock price property (Wijaya, 2018), serta tidak berdampak kepada fluktuatif indeks stock price gabungan dan indeks stock price pertambangan (Nurwani, 2016; Faizah et al., 2017; Ningsih dan Muthmainnah (2019), dan berpengaruh negatif kepada harga saham syariah (Yusuf dan Hamzah, 2014).

\section{TINJAUAN PUSTAKA}

Secara umum saham adalah suatu surat berharga yang merupakan sebuah bahan bukti atas sebagian hak pemegang atas sebuah perusahaan yang dipegang seorang investor. Berdasarkan Lintang et al. (2019), saham sendiri adalah salah satu alat pasar keuangan yang unik bagi investor dikarenakan bisa memperoleh laba lewat berinvestasi saham merupakan sebuah tanda kalau seseorang sudah berpartisipasi atau memiliki sebagian dari sebuah industri atau perseroan terbatas. Saham merupakan metode yang paling stabil untuk mendapatkan dana untuk menjalankan operasi perusahaan. Harga saham sendiri adalah harga stock price dari penawaran di umum. Definisi dari pasar modal merupakan sebuah lokasi dimana timbulnya aktivitas yang ada hubungannya bersama permohonan umum dan perbelanjaan efek, industri yang terbuka atau publik (go public) yang berhubungan dengan menerbitkan efeknya, beserta lembaga, instansi, dan karier yang berhubungan dengan efek. Berdasarkan Kurniasari et al. (2018), pasar modal adalah suatu sumber modal yang membantu acara bidang usaha ekonomi untuk memuaskan keinginan buat pribadi, negara, penanam modal dan industri. Salah satu cara untuk mempermudah masyarakat untuk melihat pergerakan pasar saham adalah menggunakan Indeks Harga Saham.

Berdasarkan Kurniasari et al. (2018), pasar modal adalah sumber keuntungan dalam berbagai badan usaha. Secara umum inflasi adalah sebuah kenaikan harga pada bahan atau 
produk dan jasa selama terus-menerus pada periode waktu tertentu. Berdasarkan Indriyani (2016), inflasi merupakan naik turun sebuah harga barang secara terus menerus atau sebuah keadaan dimana tingkat harga umum ekonomi cenderung naik. Inflasi merupakan sebuah gejala moneter, dimana turunnya sebuah angka unit moneter kepada sebuah produk (Jayanti et al., 2016). Jika ada terjadinya penyusutan angka unit moneter kepada produk dagang maka dapat kita definisi menjadi deflasi (deflation). Secara umum inflasi adalah sebuah kenaikan harga pada bahan atau produk dan jasa selama terus-menerus pada periode waktu tertentu. Berdasarkan Indriyani (2016), inflasi merupakan naik turun sebuah harga barang secara terus menerus atau sebuah keadaan dimana tingkat harga umum ekonomi cenderung naik. Inflasi merupakan sebuah gejala moneter, dimana turunnya sebuah angka unit moneter kepada sebuah produk (Jayanti et al., 2016). Consumer price index ialah standar dari biaya untuk seluruh barang ataupun jasa yang telah dibeli oleh konsumen (Mankiw et al., 2014:26).

Berdasarkan Ginting et al. (2016), kurs sendiri adalah valuta terhadap valuta negara asing, dimana nilai mata uang domestik dilihat harganya oleh mata uang asing. Nilai tukar adalah salah satu hal dalam makro ekonomi yang dihadapi oleh perusahaan. Nilai tukar atau kurs secara umum merupakan angka ataupun harga mata uang suatu negeri yang telah diukur ataupun telah diungkapkan dalam mata uang negara lain (Lintang et al., 2019). Dalam melakukan penukaran mata uang sering didengar 3 macam istilah berupa, kurs jual, kurs beli dan kurs tengah. Kurs jual membarteran mata uang asing dengan pihak penjual. Kurs beli ialah penukaran mata uang asing dengan pihak pembeli. Kurs tengah merupakan kurs yang berada diantara kurs jual dan kurs beli. Kurs tengah dihitung dengan menjumlahkan kurs beli dan kurs jual dan kemudian dibagi dua.

Utomo et al. (2019) menemukan bahwa dalam jangka panjang nilai tukar, BI rate dan inflasi mempunyai dampak negatif terhadap kinerja pasar saham. Tetapi dalam jangka pendeknya dua variabel berupa nilai tukar dan inflasi mempunyai dampak positif terhadap kinerja pasar saham sedangkan hubungan antara BI rate dengan kinerja pasar saham menunjukkan korelasi yang negatif. Ilham dan Nyoman (2019) menemukan bahwa index Nikkei 225, index Dow Jones, BI rate dan Fed rate mempunyai efek yang signifikan terhadap IHSG Indonesia periode 2006-2015 dan keempat faktor berikut mempunyai efek yang signifikan kepada nilai tukar di Indonesia periode 2006-2015. Saputra (2019) menemukan bahwa secara bersama-sama nilai tukar, tingkat suku bunga dan inflasi mempunyai dampak terhadap IHSG. Saputra (2019) juga menemukan bahwa secara parsial nilai tukar berdampak signifikan tetapi negatif terhadap IHSG, namun tingkat suku bunga dan inflasi tidak berdampak pengaruh yang signifikan terhadap IHSG.

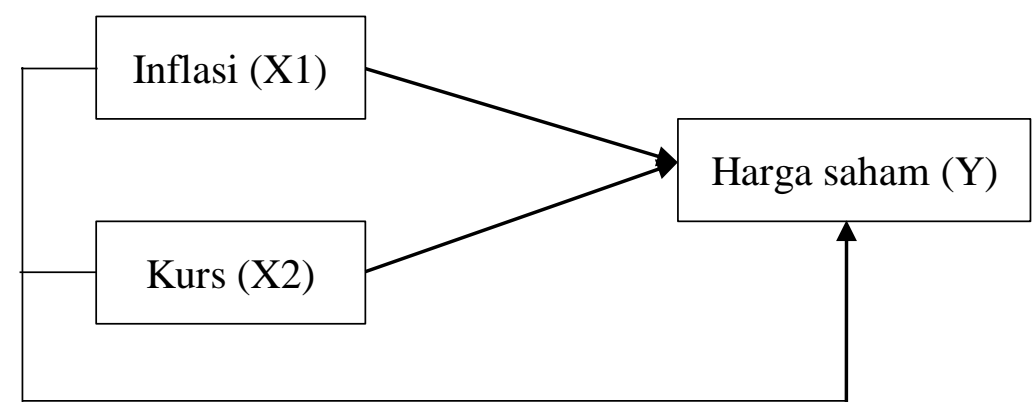

Gambar 1. Kerangka Berpikir

Berdasarkan Gambar 1, hipotesis penelitian dikembangkan sebagai berikut:

H1: Inflasi berpengaruh terhadap stock price

$\mathrm{H} 2$ : $\quad$ Kurs berpengaruh terhadap stock price

H3: Inflasi dan kurs berpengaruh terhadap stock price 


\section{METODE PENELITIAN}

Desain penelitian dibuat sebagai dasar dari penelitian dalam pembuatan. Rancangan penelitian mempunyai tujuan untuk mendapatkan penjelasan dan bukti tentang suatu kejadian yang diikuti oleh data dari suatu objek. Data yang akan di riset ini adalah data sekunder. Pada riset ini ada memakai data populasi 74 perusahaan bersifat manufaktur yang bersektor pada industri dasar dan kimia yang akan diseleksi dengan memakai cara purposive sampling. Kriteria sampel yang sudah dievaluasi berupa perusahaan yang sudah mengeluarkan ringkasan performa sepanjang periode 2015-2019, data keuangan laporan tersebut telah dikeluarkan dengan menggunakan valuta Rupiah, perusahaan belum pernah menghadapi penurunan harga saham yang negatif ataupun mengalami pemecahan saham (stock split) untuk memudahkan dalam meninterpretasikan harga saham.

Adapula sampel yang telah memuaskan standar yang digunakan dalam riset ini bertotal 18 perusahaan. Pada saat dilakukan uji normalitas terhadap data, dimana terdapat data yang tidak normal maka dilakukan uji outlier dan transform sehingga data yang digunakan oleh peneliti berjumlah 76 sampel. Teknik analisis yang akan dipakai di dalam riset berupa metode analisis kuantitatif yang akan dipakai untuk menguji hipotesis.

Teknik mengumpulkan data yang berupa data studi dokumen. Dimana peneliti akan mengumpulkan, mengolah, dan menyajikan data dalam bentuk-bentuk yang dapat dianalisis oleh orang. Data-data tersebut akan dalam bentuk dokumen dari laporan keuangan dan ringkasan performa perusahaan bersifat manufaktur yang bersektor industri dasar dan kimia yang telah terdaftar di dalam Bursa Efek Indonesia. Data yang sudah dikumpulkan akan di analisis dengan metode analisis statistik deskriptif serta uji hipotesis.

\section{HASIL PENELITIAN DAN PEMBAHASAN}

\subsection{Hasil penelitian}

Statistik deskriptif. Adalah statistik yang dapat dijadikan sebagai dasar dalam mendeskripsikan dan menggambarkan data yang telah didapatkan tanpa menarik sebuah hasil yang konsisten secara umum atau generalisasi. Dapat kita simpulkan dari Tabel 2 bahwa, faktor data inflasi ada standar deviasi sebanyak 0,32868 dengan angka terendah sebanyak 2,72, angka maksimum 3,61 dan angka rata-rata sebanyak 3,1741. Faktor kurs ada standar deviasi sebanyak 270,328 dengan angka terendah sebanyak 13436, angka maksimum 14481 dan angka rata-rata sebanyak 13726,20. Tetapi faktor harga saham ada standar deviasi sebanyak 282,211 dengan angka terendah sebanyak 62, nilai maksimum sebanyak 1170 dan nilai rata-rata sebanyak 465,95.

Tabel 2. Statistik deskriptif

\begin{tabular}{lrrrrr}
\hline & N & \multicolumn{1}{c}{ Minimum } & Maximum & \multicolumn{1}{c}{ Mean } & Std. Deviation \\
\hline Inflasi (X1) & 76 & 2.72 & 3.61 & 3.1741 & 0.32868 \\
Kurs (X2) & 76 & 13436 & 14481 & 13726.20 & 270.328 \\
Harga Saham (Y) & 76 & 62 & 1170 & 465.95 & 282.211 \\
$\quad$ Valid N (listwise) & 76 & & & & \\
\hline
\end{tabular}

\section{Uji hipotesis}

1. Uji t. Uji t ini menunjukkan berapa jauh konsekuensi satu faktor tidak terikat sewaktu menjelaskan perbedaan faktor terikat. Sebuah faktor tidak terikat mempunyai dampak kepada faktor terikat kalau faktor tersebut telah lulus tes uji signifikan. Pada pengujian t, maka hasil yang diperhatikan menunjukkan:

- Faktor Inflasi (X1) mempunyai angka signifikan sebanyak 0,717 >0,05 dan angka t hitung sebanyak $0,363<\mathrm{t}$ tabel sebanyak 1,99346 jadi kita dapat simpulkan kalau Ho 
kita terima dan Ha kita tolak, soal ini memiliki arti bahwa adanya dampak positif yang tidak signifikan secara parsial di antara faktor inflasi kepada harga saham.

- Faktor Kurs (X2) mempunyai angka signifikan sebanyak 0,001 <0,05 dan angka t hitung sebanyak 3,643 > t tabel sebanyak 1,99346 jadi kita dapat simpulkan kalau Ho kita tolak dan Ha kita terima, soal ini memiliki arti bahwa adanya dampak positif yang signifikan secara parsial di antara faktor kurs kepada harga saham.

Tabel 3. Uji t

\begin{tabular}{|c|c|c|c|c|c|}
\hline \multirow{2}{*}{ Model } & \multicolumn{2}{|c|}{$\begin{array}{l}\text { Unstandardized } \\
\text { Coefficients }\end{array}$} & \multirow{2}{*}{$\begin{array}{c}\begin{array}{c}\text { Standardized } \\
\text { Coefficients }\end{array} \\
\text { Beta }\end{array}$} & \multirow[t]{2}{*}{$\mathbf{t}$} & \multirow{2}{*}{ Sig. } \\
\hline & B & Std. Error & & & \\
\hline Constant & -273.572 & 87.688 & & -3.120 & 0.003 \\
\hline Inflasi (X1) & 2.928 & 8.059 & 0.042 & 0.363 & 0.717 \\
\hline Kurs (X2) & 2.633 & 0.723 & 0.466 & 3.643 & 0.001 \\
\hline
\end{tabular}

2. Uji F. Uji ini memberitahu apakah semua variabel independen di dalam model regresi linear berganda memiliki dampak secara simultan kepada faktor terikat. Dilihat dari hasil luaran Tabel 4, telah diperoleh angka signifikan sebanyak 0,002 $<0,05$ dan angka $F$ hitung sebanyak 5,245 > F tabel sebanyak 2,73 maka kita dapat mensimpulkan kalau inflasi dan kurs secara simultan memiliki dampak positif dan secara signifikan terhadap harga saham.

Tabel 4. Uji F

\begin{tabular}{lccccc}
\hline \multicolumn{1}{c}{ Model } & Sum of Squares & df & Mean Square & F & Sig. \\
\hline Regression & 566.572 & 3 & 188.857 & 5.245 & 0.002 \\
Residual & 2592.492 & 72 & 36.007 & & \\
Total & 3159.064 & 75 & & & \\
\hline
\end{tabular}

3. Uji koefisien determinasi. Uji ini merupakan hasil ukuran yang mengindikasikan nilai perbandingan faktor sebuah faktor yang tidak terikat dapat menerangkan faktor-faktor yang terikat. Diobservasi hasil uji tabel 5 dapat kita ketahui kalau angka R2 sebanyak 0,145. Ini merupakan persentase sumbangan variabel inflasi (X1) dan kurs (X2) dalam model regresi memiliki nilai berupa 14,5\%. Maka sumbangan dari variabel independen dapat dihitung menjadi 14,5\% sedangkan sisa sebesar 85,5\% dapat diberi pengaruh dari faktor yang tidak dapat diriset oleh peneliti di dalam riset.

Tabel 5. Uji Koefisien Determinasi

\begin{tabular}{cccc}
\hline $\mathbf{R}$ & R Square & Adjusted R Square & Std. Error of the Estimate \\
\hline 0.423 & 0.179 & 0.145 & 6.00057 \\
\hline
\end{tabular}

\subsection{Pembahasan}

Pengaruh inflasi kepada harga saham. Variabel inflasi (X1) mempunyai angka signifikan sebanyak 0,717 $>0,05$ dan angka $t_{\text {hitung }}$ sebanyak $0,363<t_{\text {tabel }}$ sebanyak 1,99346 simpulan inflasi berpengaruh positif tidak signifikan kepada harga saham. Hal ini telah sama seperti riset terdahulu yang dilaksanakan Ginting et al. (2016), Lintang et al. (2019), Mamahit et al. (2019), Martha dan Yanti (2019), dan Saputra (2019) dimana inflasi secara parsial berpengaruh namun tidak signifikan terhadap stock price. Pendapat ini memberitahukan kalau meningkatnya inflasi secara menerus adalah hal yang negatif buat orang yang ingin berinvestasi dikarenakan meningkatnya penghasilan dan pengeluaran industri yang sejalan dengan tingkat inflasi dapat membuat orang berpendapat dalam investasi dan menurunnya harga saham. 
Pengaruh kurs kepada harga saham. Variabel kurs (X2) mempunyai angka signifikan sebanyak $0,001<0,05$ dan angka $t_{\text {hitung }}$ sebanyak 3,643 $<\mathrm{t}_{\text {tabel }}$ sebanyak 1,99346 simpulan berpengaruh positif dan signifikan kepada harga saham. Pendapat ini sama seperti riset terdahulu yang dilaksanakan Saputra (2019), Ginting et al. (2016), Mamahit et al. (2019), dan Martha dan Yanti (2019) dimana kurs secara parsial berdampak terhadap stock price gabungan. Pendapat ini muncul karena melemahnya atau menguatnya kurs bisa menjadi penyebab meningkatnya atau menurunnya pendapatan dan biaya industri yang memakai valuta asing atau didalam kegiatan ekspor dan impor yang bisa menaikkan ataupun menurunkan saham sebuah industri.

Pengaruh inflasi dan kurs kepada harga saham. Uji F mempunyai hasil membuktikan kalau angka signifikan 0,002 <0,05 dan angka $F_{\text {hitung }}$ sebanyak 5,245 $>F_{\text {tabel }}$ sebanyak 2,73 maka kalau kita simpulkan inflasi dan kurs secara simultan berpengaruh positif dan secara signifikan kepada harga saham. Riset ini mempunyai hasil sama seperti riset terdahulu yang dilaksanakan Ginting et al. (2016), dan Mamahit et al. (2019) yang berpendapat kalau inflasi dan kurs secara simultan mempunyai pengaruh kepada stock price dikarenakan hal tersebut sangat mempengaruhi keuntungan usaha.

\section{KESIMPULAN}

Dari hasil analisis data, uji hipotesis yang sudah pernah disusun dan dijelaskan bisa kita simpulkan sebagai berikut:

- Inflasi berpengaruh positif dan tidak signifikan kepada harga saham dengan angka t hitung sebanyak $0,363<\mathrm{t}$ tabel sebanyak 1,99346 dan angka signifikan sebanyak 0,717 > 0,05 .

- Kurs berpengaruh positif dan signifikan kepada harga saham dengan angka t hitung sebanyak 3,643>t tabel sebanyak 1,98861 dan angka signifikan sebanyak 0,001<0,05.

- Inflasi dan kurs secara simultan berpengaruh positif dan secara signifikan kepada harga saham dengan angka $\mathrm{F}$ hitung sebanyak 5,245 > F tabel sebanyak 2,73 dan angka signifikan sebanyak $0,002<0,05$.

\section{DAFTAR PUSTAKA}

Efriyenti, D. (2017). Pengaruh earning per share dan dividend per share terhadap harga saham pada Bank Riau Kepri Kota Batam. Jurnal Akuntansi Barelang, 1(2), 15-25. http://ejournal.upbatam.ac.id/index.php/jab/article/view/167

Faizah, N. I., Rachmansyah, Y., \& Anoraga, P. (2017). Analisis pengaruh inflasi, harga minyak dunia dan nilai kurs dolar (USD/IDR) terhadap Indeks Harga Saham Gabungan (IHSG) di Bursa Efek Indonesia (BEI) periode 2011-2014. Magisma: Jurnal Ilmiah Ekonomi Dan Bisnis, 5(2), 34-38. https://doi.org/10.35829/magisma.v5i2.25

Ginting, M. R. M., Topowijono, \& Sulasmiyati, S. (2016). Pengaruh tingkat suku bunga, nilai tukar dan inflasi terhadap harga saham (Studi pada Sub-Sektor Perbankan di Bursa Efek Indonesia periode 2011-2015). Jurnal Administrasi Bisnis, 35(2), 77-85. http://administrasibisnis.studentjournal.ub.ac.id/index.php/jab/article/view/1371

Ilham, K. R., \& Nyoman, S. I. A. (2019). The influence of world stock index, BI Rate and fed rate through IHSG on exchange rates in Indonesia for the period of 2006-2015. Russian Journal of Agricultural and Socio-Economic Sciences, 9(93), 216-226. https://doi.org/10.18551/rjoas.2019-09.23

Indriyani, S. N. (2016). Analisis pengaruh inflasi dan suku bunga terhadap pertumbuhan ekonomi di Indonesia tahun 2005-2015. Jurnal Manajemen Bisnis Krisnadwipayana, 
4(2), 1-11. http://ojs.ekonomi-unkris.ac.id/index.php/JMBK/article/view/37

Jayanti, S. D., Anwar, D., \& Fitri, A. (2016). Pengaruh inflasi dan BI Rate terhadap pembiayaan usaha mikro kecil dan menengah (Studi kasus pada Bank Umum Syariah). I-ECONOMICS: A Research Journal on Islamic Economics, 2(2), 86-105. http://jurnal.radenfatah.ac.id/index.php/ieconomics/article/view/1026

Kurniasari, W., Wiratno, A., \& Yusuf, M. (2018). Pengaruh inflasi dan suku bunga terhadap return saham dengan profitabilitas sebagai variabel intervening di perbankan yang terdaftar di Bursa Efek Indonesia tahun 2013-2015. Journal of Accounting Science, 2(1), 67-90. https://doi.org/10.21070/jas.v2i1.1216

Lintang, D. L., Mangantar, M., \& Baramuli, D. N. (2019). Pengaruh tingkat inflasi dan tingkat nilai tukar rupiah terhadap harga saham perusahaan manufaktur sektor industri barang konsumsi di Bursa Efek Indonesia periode 2013-2017. Jurnal Riset Ekonomi, Manajemen, Bisnis dan Akuntansi, 7(3), 2791-2800. https://ejournal.unsrat.ac.id/index.php/emba/article/view/23743

Mamahit, R. R., Tumbel, T. M., \& Mangindaan, J. V. (2019). Pengaruh Variabel Makroekonomi Terhadap Indeks Harga Saham Gabungan (Studi pada Indeks Harga Saham Gabungan di Bursa Efek Indonesia periode 2014-2018). Jurnal Administrasi Bisnis (JAB), 8(2), 75-82. https://doi.org/10.35797/jab.8.2.2019.23565.75-82

Mankiw, N. G., Quah, E., \& Wilson, P. (2014). Perhitungan Biaya Hidup. in D. A. Halim, L. Febrina, D. J. Asmara, \& D. Hasbiy (Eds.), Pengantar Ekonomi Makro (2nd ed.). Jakarta: Salemba Empat dan Cengage Learning.

Martha, \& Yanti, F. (2019). Pengaruh inflasi, nilai kurs, ROA, DER, dan PBV terhadap harga saham perusahaan retail di BEI tahun 2010-2017. Jurnal Ilmiah Akuntansi, 3(1), 110123.http://www.ejournal.pelitaindonesia.ac.id/ojs32/index.php/BILANCIA/article/vie $\mathrm{w} / 404$

Ningsih, Y. I., \& Muthmainnah. (2019). Pengaruh inflasi, kurs, suku bunga, dan harga minyak dunia terhadap Indeks Harga Saham Industri Pertambangan di Bursa Efek Indonesia periode 2012-2015. Ekonomis: Journal of Economics and Business, 3(1), 18-26. https://doi.org/10.33087/ekonomis.v3i1.52

Nurwani. (2016). Analisis pengaruh inflasi, nilai tukar rupiah, dan suku bunga SBI terhadap pergerakan Indeks Harga Saham Gabungan di Bursa Efek Indonesia. EKONOMIKAWAN: Jurnal Ilmu Ekonomi dan Studi Pembangunan, 16(2), 1-13. https://doi.org/10.30596/ekonomikawan.v16i2.945

Saputra, A. (2019). Pengaruh nilai tukar, suku bunga, dan inflasi terhadap Indeks Harga Saham Gabungan di Bursa Efek Indonesia. Journal of Islamic Economic and Banking, 2(2), 1-15. http://journal.stebisdarussalamoki.ac.id/index.php/khozana/article/view/26

Utomo, H. S., Wulandari, D., Shandy Narmaditya, B., Handayati, P., \& Ishak, S. (2019). Macroeconomic factors and LQ45 stock price index: Evidence from Indonesia. Investment Management and Financial Innovations, 16(3), 251-259. https://doi.org/10.21511/imfi.16(3).2019.23

Wijaya, I. G. N. K. S. (2018). Analisis pengaruh nilai tukar Rupiah, tingkat suku bunga SBI dan laju inflasi terhadap indeks harga saham property (Studi pada Bursa Efek Indonesia periode 2008-2011). Jurnal Ilmu Manajemen (JUIMA), 8(2), 128-136. http://e-journal.unmas.ac.id/index.php/juima/article/view/294

Yusuf, A. A., \& Hamzah, A. (2014). Pengaruh inflasi, suku bunga, nilai tukar/kurs, dan IHSG terhadap harga saham syariah pendekatan error correction model. Al-Amwal: Jurnal $\begin{array}{llll}\text { Ekonomi dan Perbankan } & \text { Syari'ah, }\end{array}$ https://www.syekhnurjati.ac.id/jurnal/index.php/amwal/article/view/247 